\title{
PELAKSANAAN VERIFIKASI PERALIHAN HAK ATAS TANAH DAN BANGUNAN (BPHTB) DI KABUPATEN BOGOR
}

\author{
Dina Erlinda, Fifiana, Wiesnaeni, Novira Maharani Sukma \\ Program Studi Magister Kenotariatan \\ Fakultas Hukum, Universitas Diponegoro \\ Email : erlinadina2121@gmail.com
}

\begin{abstract}
Bogor Regency DPKAD policy in conducting verification and validation to determine the market value of the tax object, this is related to legal certainty in the case of transfer of rights to land and buildings. Problems in this study: How is Juridical Analysis of the Determination of Transaction Price of Transition of Rights in Verification of Obligation of Acquisition of Land and Building Rights (BPHTB) in Bogor Regency? and What are the obstacles in determining the transaction price of the transfer of land and building rights in the BPHTB Verification towards the smooth running of community services? The method used is the Empirical Juridical approach. Sources and types of data used are divided into two, namely primary data and secondary data. There are two data collection techniques; field study and literature study. Analysis of the data used is qualitative analysis. The results of this study are: 1) The Implementation of The Transitional Transaction Price Determination in BPHTB Verification in Bogor Regency is based on the value of the transaction that occurred over the sale and purchase of land rights. SSPD BPHTB is far from the value of the transaction price.
\end{abstract}

Keywords: Policy; DPKAD; BPHTB.

\begin{abstract}
ABSTRAK
Kebijakan DPKAD Kabupaten Bogor dalam melakukan verifikasi dan validasi untuk menentukan nilai pasar dari obyek pajak, hal ini berkaitan dengan kepastian hukum dalam hal peralihan hak atas tanah dan bangunan. Permasalahan dalam penelitian ini: Bagaimana Analisis Yuridis Terhadap Penentuan Harga Transaksi Peralihan Hak Dalam Verifikasi Bea Perolehan Hak Atas Tanah Dan Bangunan (BPHTB) Di Kabupaten Bogor? dan Bagaimana kendala penentuan harga transaksi peralihan hak atas tanah dan bangunan dalam Verifikasi BPHTB terhadap terhadap kelancaran pelayanan masyarakat?. Metode pendekatan yang digunakan adalah pendekatan Yuridis Empiris. Sumber dan jenis data yang dipergunakan dibagi menjadi dua, yaitu data primer dan data sekunder. Teknik pengumpulan data ada dua; studi lapangan dan studi kepustakaan. Analisa data yang digunakan adalah analisa Kualitatif. Hasil dari penelitian ini adalah 1) Pelaksanaan Penentuan Harga Transaksi Peralihan Hak Dalam Verifikasi BPHTB di Kabupaten Bogor adalah berdasarkan nilai transaksi yang terjadi atas jual beli hak atas tanah.2) Kendala Penentuan Harga Transaksi Peralihan Hak Dalam Verifikasi BPHTB yaitu nilai yang digunakan pada saat pengisian SSPD BPHTB jauh dari pada nilai harga transaksi.
\end{abstract}

Kata Kunci : Kebijakan; DPKAD; Bea Perolehan Hak Atas Tanah Dan Bangunan 


\section{A. Pendahuluan}

Pajak merupakan sumber penerimaan negara yang sangat penting dalam menopang pembiayaan pembangunan yang bersumber dari dalam negeri. Pemerintah dalam melaksanakan pemungutan pajak harus berdasarkan keadilan serta memberikan kepastian hukum bagi pembayar pajak tanpa memandang pajak sebagai beban melainkan sebagai suatu kewajiban kenegaraan yang harus dipenuhi sebagai anggota masyarakat yang mendapatkan pelayanan dari pemerintah (Siahaan, 2004). Besar kecilnya pajak akan menentukan kapasitas anggaran negara dalam membiayai pengeluaran negara, baik untuk pembiayaan pembangunan maupun untuk pembiayaan anggaran rutin.

Secara umum dapat dikatakan bahwa pajak adalah pungutan dari masyarakat kepada negara (pemerintah) berdasarkan Undang-Undang yang bersifat dapat dipaksakan dan terutang oleh yang wajib membayarnya dengan tidak mendapat prestasi kembali (kontra prestasi/balas jasa) secara langsung yang hasilnya digunakan untuk membiayai pengeluaran negara dalam penyelenggaraan pemerintahan dan pembangunan.

Dalam pasal itu ditegaskan bahwa pengenaan dan pemungutan pajak (termasuk bea dan cukai) untuk keperluan negara hanya boleh terjadi berdasarkan Undang-Undang (Bohari, 2008). Pajak tidak memberikan imbalan yang secara langsung dapat ditunjuk. Bangunan juga memberi manfaat ekonomi bagi pemiliknya. Oleh karena itu bagi mereka yang memperoleh hak atas tanah dan bangunan, wajib menyerahkan sebagian nilai ekonomi yang diperolehnya kepada negara melalui pembayaran pajak, yang dalam hal ini Bea Perolehan Hak atas Tanah dan Bangunan (BPHTB) (Rusjdi, 2005).

BPHTB adalah pajak yang dikenakan atas perolehan hak atas tanah dan atau bangunan, yang selanjutnya disebut pajak. Dengan demikian objek pajak BPHTB adalah tanah, bangunan serta tanah yang disertai bangunan. (Damayanti, 2005) Seiring dengan pelaksanaan otonomi daerah , BPHTB yang sebelumnya dikelola oleh Pemerintah Pusat, berdasarkan Undang-Undang Nomor 28 Tahun 2009 tentang Pajak Daerah dan Retribusi Daerah (PBDR) khususnya Pasal 85 s.d Pasal 93 dilimpahkan menjadi kewenangan daerah. Pengalihan BPHTB dari pajak pusat menjadi pajak daerah merupakan langkah strategis dalam pelaksanaan desentralisasi fiscal di Indonesia. Disamping memiliki justifikasi teknis, pengalihan BPHTB menjadi pajak daerah akan dapat meningkatkan pendapatan asli daerah (PAD) sebagai salah satu sarana untuk meningkatkan kualitas belanja daerah (local spending quality). (Kementerian Keuangan Republik Indonesia, Direktorat Jenderal Perimbangan Keuangan, 2011) 
BPHTB pada hakikatnya merupakan salah satu pajak objektif atau pajak kebendaan dimana pajak terutang didasarkan pertama-tama pada apa yang menjadi objek pajak baru kemudian memerhatikan siapa yang menjadi objek pajak baru kemudian memerhatikan siapa yang menjadi subjek pajak. Pemungutan BPHTB salah satunya dapat dilakukan dengan cara self assessment system, Self assessment system adalah sistem perpajakan yang inisiatif untuk memenuhi kewajiban perpajakan berada di Wajib Pajak, (Nurmana, 2003) pada pelaksanaanya wajib pajak diberikan kepercayaan untuk menghitung sendiri serta membayar sendiri pajak yang terutang dengan menggunakan Surat Setoran Pajak Daerah Bea Perolehan Hak Atas Tanah dan Bangunan (SSPD BPHTB) meskipun pada prakteknya, yang melakukan perhitungan adalah Notaris selaku Pejabat Pembuat Akta Tanah (PPAT). Sistem self assessment yang diterapkan di Indonesia dalam meningkatkan penerimaan pajak tidaklah mudah dan mengandung banyak kelemahan. Salah satunya adalah sangat tergantung pada kejujuran wajib pajak, apabila wajib pajak tidak jujur, maka tidak mudah bagi petugas pajak untuk menghitung pajak yang terutang sehingga benar.

Kerangka teori merupakan teori yang dibuat untuk memberikan gambaran yang sistematis mengenai masalah yang diteliti. Teori ini masih bersifat sementara yang akan dibuktikan kebenarannya dengan cara meneliti dalam realitas. Dalam penelitian hukum, adanya kerangka konsepsional dan kerangka teoritis menjadi syarat yang penting. Didalam kerangka teoritis diuraikan segala sesuatu yang terdapat dalam teori sebagai suatu sistem aneka ajaran yang dalam bahasa Belanda disebut leerstelling.(Soekanto dan Mamudji, 2003)

Teori merupakan rangkaian asumsi, konsep, definisi, untuk mengembangkan, menekankan serta menerangkan suatu gejala sosial secara sistematis. Pada prinsipnya suatu teori adalah hubungan antara dua fakta atau lebih, atau pengaturan fakta menurut cara-cara tertentu fakta tersebut merupakan suatu yang dapat diamati dan pada umumnya dapat diuji secara empiris, oleh sebab itu dalam bentuknya yang paling sederhana, suatu teori merupakan hubungan antara dua variabel atau lebih yang telah diuji kebenarannya. (Soekamto, 2001)

Teori-teori dan pendapat para ahli sangat dibutuhkan dalam menjawab permasalahan dalam penulisan ini. Teori-teori dan pendapat para ahli tersebut antara lain :

\section{a. Teori dan Sistem Pemungutan Pajak}

Timbulnya utang pajak dalam hukum pajak didasarkan pada dua ajaran yang berbeda, yaitu ajaran Material dan ajaran Formal.

1) Ajaran Material

Menurut ajaran Material, utang pajak (perikatan pajak) timbul karena Undang-Undang pada saat dipenuhi tatbestand (keadaan, peristiwa, perbuatan). Jadi menurut ajaran ini 
apabila tatbestand itu sudah dipenuhi, maka dengan sendirinya timbul utang pajak, walaupun belum ada surat ketetapan.

2) Ajaran Formal

Ajaran Formal mengatakan bahwa utang pajak baru timbul pada saat dikeluarkannya Surat Ketetapan Pajak (SKP). Jadi selama belum ada SKP, belum ada utang pajak walaupun tatbestand sudah dipenuhi.

Sistem pemungutan yang dapat digunakan ada 3 (tiga), yaitu: (Munawir, 1992)

1) Official Assessment System, yaitu suatu sistem pemungutan pajak dimana wewenang untuk menentukan besarnya pajak yang terutang oleh seseorang berada pada Pemungut Pajak (Fiskus). Dalam sistem ini masyarakat Wajib Pajak bersifat pasif menunggu ketetapan dari Aparatur Pajak atau Pemungut Pajak.

2) Self Assessment System, yaitu suatu sistem pemungutan pajak yang memberikan wewenang kepada Wajib Pajak untuk menentukan sendiri besarnya pajak yang terutang.

3) With Holding System, yaitu suatu sistem pemungutan pajak yang memberi wewenang kepada pihak ketiga (bukan fiskus dan bukan Wajib Pajak yang bersangkutan).untuk menentukan besarnya pajak yang terhutang oleh Wajib Pajak. Contoh pihak ketiga yang dimaksud dalam sistem ini misalnya: konsultan pajak, akuntan publik, Wajib Pungut atau Wajib Potong dan sebagainya.

Teori Sistem Pemungutan Pajak dapat digunakan untuk menganalisa terhadap penentuan harga transaksi peralihan hak dalam verifikasi Bea Perolehan Hak Atas Tanah Dan Bangunan (BPHTB) di Kabupaten Bogor. (Marzuki, 2008)

\section{b. Teori Kebijakan}

Kebijakan menurut Friedrich dalam Winarno (Budi, 2007), adalah sebagai suatu arah tindakan yang diusulkan oleh seseorang, kelompok atau pemerintah dalam suatu lingkungan tertentu yang memberikan hambatan-hambatan dan peluang-peluang terhadap kebijakan yang diusulkan untuk menggunakan dan mengatasi dalam rangka mencapai suatu tujuan atau merealisasikan suatu sasaran atau suatu maksud tertentu.

Menurut James E. Anderson dalam Lubis (Solly, 2014), kebijakan adalah serangkaian tindakan yang mempunyai tujuan tertentu yang diikuti dan dilaksanakan oleh seorang pelaku atau sekelompok pelaku guna memecahkan suatu masalah tertentu.

Self assessment system yang dianut Undang-Undang perpajakan Indonesia memberi kepercayaan penuh terhadap wajib pajak untuk menghitung, menyetor dan melaporkan sendiri kewajiban perpajaknnya kepada pemungut pajak (fiskus) dengan 
menggunakan dokumen Surat Pemberitahuan (SPT), dengan kata lain bahwa wajib pajak aktif mulai menghitung, memperhitungkan, menyetor dan melaporkan pajak yang terutang sendiri dan fiskus pada system ini bersifat pasif, yaitu hanya memberikan pelayanan, penerangan, pengawasan dan pemeriksanaan.

Teori Kebijakan dapat digunakan untuk menganalisa penentuan harga transaksi peralihan hak atas tanah dan bangunan dalam Verifikasi BPHTB terhadap terhadap kelancaran pelayanan masyarakat. (Sudirman, 2007)

Adapun pokok pembahasannya lebih menyoroti tentang bagaimana perolehan hak atas tanah dan bangunan di Kabupaten Bogor. Hal ini bertujuan untuk mengetahui pelaksanaan penentuan harga transaksi peralihan hak dalam verifikasi Bea Perolehan Hak Atas Tanah Dan Bangunan (BPHTB) di Kabupaten Bogor. Dari uraian-uraian dan latar belakang masalah yang telah penulis uraikan diatas maka dapat dirumuskan masalah sebagai berikut: 1) Bagaimana pelaksanaan penentuan harga transaksi peralihan hak dalam verifikasi Bea Perolehan Hak Atas Tanah Dan Bangunan (BPHTB) di Kabupaten Bogor? 2) Bagaimana kendala penetuan harga transaksi peralihan hak dalam verifikasi Bea Perolehan Hak Atas Tanah Dan Bangunan (BPHTB) serta solusi penyelesainnya?

Penelitian ini merupakan hasil karya sendiri. Peneliti mendapatkan sumber dari studi kepustakaan yang menjadi rujukan, acuan, pemahaman teori dan pengutipan yang dapat dinyatakan kebenarannya. Peneliti melakukan perbandingan terhadap tiga penelitian yang dilakukan sebelumnya yang termuat dan dirumuskan sebagai berikut:

Kepastian Nilai Dasar Penghitungan Bea Perolehan Hak Atas Tanah dan Bangunan (BPHTB) (Murjiyanto, dan Ismaya, 2015). Permasalahan dalam penelitian ini adalah bagaimanakah kepastian nilai perhitungan BPHTB dalam peralihan hak atas tanah? Penggunaan nilai transaksi sebagai dasar perhitungan BPHTB menimbulkan ketidakpastian, baik nilai transaksinya yang bisa berubah, perhitungan maupun jumlah pajak yang harus dibayar oleh wajib pajak, setelah hasil validasi yang dilakukan oleh dinas pengelola BPHTB, disamping keharusan validasi melalui proses yang memakan waktu dan berakibat menghambat proses pendaftaran peralihan hak atas tanah.

Penentuan Harga Jual Beli Tanah Dalam Pemungutan Bea Perolehan Hak Atas Tanah Dan Bangunan Di Kota Pekanbaru (Alwi, dan Yuslim, 2018). Permasalahan dalam penelitian ini adalah bagaimana penentuan harga jual beli tanah dalam pemungutan BPHTB di Kota Pekanbaru? Penentuan harga jual beli tanah dan bangunan oleh BAPENDA Kota Pekanbaru dalam pemungutan BPHTB terutang dilakukan dengan cara melakukan penyesuaian terhadap 
SPPT PBB tahun saat pelaporan SSPD BPHTB dengan ketetapan besarnya NJOP PBB yang telah disesuaikan berdasarkan Keputusan Walikota Pekanbaru untuk periode setiap tahunnya.

Mekanisme Dalam Menentukan Nilai Pasar Pada Pemungutan BPHTB Atas Waris Di Kota Surabaya Oleh Dinas Pendapatan Dan Pengelolaan Keuangan Kota Surabaya (Maulidah, 2015). Permasalahan dalam penelitian ini adalah bagaimana mekanisme dalam menentukan nilai pasar pada pemungutan BPHTB atas waris di kota Surabaya oleh Dinas Pendapatan dan Pengelolaan Keuangan kota Surabaya ? Mekanisme dalam menentukan nilai pasar pada pemungutan BPHTB atas waris di kota Surabaya yang dilakukan oleh DPKAD kota Surabaya yaitu pertama, orang bagian Survey mensurvey atau datang ke lokasi untuk melakukan pendataan setelah berkas BPHTB atas waris yang diajukan oleh Wajib Pajak (WP) ke DPKAD kota Surabaya.

\section{B. Metode Penelitian}

Metode yang digunakan dalam penelitian ini adalah metode penelitian yuridis empiris. Yuridis mengandung makna bahwa penelitian ini dianalisis menggunakan berbagai buku-buku, peraturan perundang-undangan di bidang kenotariatan sebagai data sekunder. Penelitian yang akan dilakukan menggunakan metode penelitian hukum sosiologis atau empiris.(Amiruddin, dan Asikin, 2004) Metode yuridis empiris dalam penelitian ini meninjau dan melihat serta menganalisa permasalahan yang menjadi objek penelitian yaitu mengenai penentuan harga hransaksi peralihan hak dalam verifikasi Bea Perolehan Hak Atas Tanah Dan Bangunan (BPHTB) di Kabupaten Bogor. Spesifikasi penelitian ini adalah penelitian adalah Deskriptif Analitis. Sumber dan jenis data yang dipergunakan dalam penelitian ini dibagi menjadi dua, yaitu data primer dan data sekunder. Dalam penelitian ini teknik pengumpulan data ada dua; studi lapangan dan studi kepustakaan. Analisa data yang digunakan dalam penelitian ini adalah analisa Kualitatif.

\section{Hasil Dan Pembahasan}

1. Pelaksanaan Penentuan Harga Transaksi Peralihan Hak Dalam Verifikasi Bea Perolehan Hak Atas Tanah Dan Bangunan (BPHTB) Di Kabupaten Bogor

a. Seting Sosial Pengelolaan Pajak dan Pendapatan Daerah di Kabupaten Bogor

Penyelenggaraan Otonomi Daerah sejak berlakunya Undang-undang Nomor 32 Tahun 2004 tentang Pemerintahan Daerah dilaksanakan dengan memberikan kewenangan yang luas, nyata dan bertanggung jawab kepada Daerah. Pemberian kewenangan tersebut tidak semata-mata pelimpahan kekuasaan saja, melainkan juga adanya perubahan pola hubungan keuangan antara pusat dan daerah sebagaimana tertuang dalam Undang-undang Nomor 33 Tahun 2004 tentang Perimbangan keuangan antara Pemerintah Pusat dan Daerah. Sebagai konsekwensinya Pemerintah daerah harus memperhatikan satu aspek yang 
berkaitan dengan pengelolaan keuangan daerah dalam rangka menjalankan fungsinya memberikan pelayanan kepada masyarakat. Pemerintah Kabupaten Bogor, dalam rangka melaksanakan Otonomi Daerah membentuk Dinas Pengelolaan Keuangan dan Aset Daerah Kabupaten Bogor atau yang lebih dikenal DPKAD Kabupaten Bogor, yang merupakan organisasi baru hasil penggabungan Dinas Pendapatan Daerah Kabupaten Bogor (Dipenda) dengan Bagian Keuangan Setda Kabupaten Bogor.

Sektor pendapatan daerah memegang peranan yang sangat penting, karena melalui sektor ini dapat dilihat sejauh mana suatu daerah dapat membiayai kegiatan pemerintah dan pembangunan daerahnya sendiri. Daerah dituntut untuk berperan aktif dalam mengoptimalkan penerimaan pendapatan daerahnya. Hal tersebut sebagai upaya untuk menggali pendanaan dalam pelaksanaan otoda (otonomi daerah) sebagai perwujudan asas desentralisasi.

b. Kebijakan Dinas Pengelolaan Keuangan dan Aset Daerah (DPKAD) Kabupaten Bogor dalam Penentuan Nilai Jual atas Tanah dalam Bea Perolehan Hak Atas Tanah dan Bangunan (BPHTB).

Salah satu kebijakan yaitu terkait perpajakan, berdasarkan Undang-Undang Nomor 6 Tahun 1983 yang telah mengalami dua kali perubahan, yaitu perubahan pertama UndangUndang Nomor 10 Tahun 1994 dan perubahan kedua Undang-Undang Nomor 16 Tahun 2000 tentang Ketentuan Umum dan Tata Cara Perpajakan, diketahui bahwa sistem pemungutan pajak di Indonesia menganut self assessment system menggantikan system pemungutan pajak official assessment system.

Self assessment system yang dianut Undang-Undang perpajakan Indonesia memberi kepercayaan penuh terhadap wajib pajak untuk menghitung, menyetor dan melaporkan sendiri kewajiban perpajaknnya kepada pemungut pajak (fiskus) dengan menggunakan dokumen Surat Pemberitahuan (SPT), dengan kata lain bahwa wajib pajak aktif mulai menghitung, memperhitungkan, menyetor dan melaporkan pajak yang terutang sendiri dan fiskus pada system ini bersifat pasif, yaitu hanya memberikan pelayanan, penerangan, pengawasan dan pemeriksanaan.

Teori Kebijakan dapat digunakan untuk menganalisa penentuan harga transaksi peralihan hak atas tanah dan bangunan dalam Verifikasi BPHTB terhadap terhadap kelancaran pelayanan masyarakat. Sumber-sumber penerimaan daerah dalam pelaksanaan otonomi daerah menurut Undang-Undang Nomor 32 Tahun 2004 dan Undang-Undang Nomor 33 Tahun 2004 pasal 5 ayat (2) terdiri dari pendapatan asli daerah, dana perimbangan, dan lain-lain pendapatan asli daerah yang sah. Dalam penerimaan dana 
perimbangan, salah satunya merupakan penerimaan Bea Perolehan Hak atas Tanah dan Bangunan (BPHTB). Bea Perolehan Hak atas Tanah dan Bangunan (BPHTB) adalah pajak yang bersifat kebendaan dalam arti besarnya pajak ditentukan oleh keadaan nilai jual objek pajak yaitu bumi/tanah dan atau bangunan. Keadaan subjek (siapa yang membayar) tidak ikut menentukan besarnya pajak. Kemudian dengan dikeluarkannya Peraturan Bupati Bogor Nomor 37 Tahun 2008 tentang Penjabaran Tugas dan Fungsi Dinas Pengelolaan Keuangan dan Aset Daerah Kabupaten Bogor. Diharapkan mampu meningkatkan pendapatan daerah. (Harsono, 2007)

Bea Perolehan Hak atas Tanah dan Bangunan dikenakan bagi pihak baik perseorangan maupun badan hukum yang memperole hak atas tanah dan bangunan. Seseorang atau badan hukum dapat memperoleh hak atas tanah dan bangunan dapat berasal dari beberapa sebab, antara lain karena jual beli, hibah, warisan, tukar menukar dan lainlain. Jual-beli sebagai salah satu sebab seseorang memperoleh hak atas tanah dan bangunan pada hakekatnya sebagai perbuatan pengalihan hak kepada pihak/orang lain dari penjual kepada pembeli.(Rashid, 1987)

Bea Perolehan Hak Atas Tanah dan Bangunan (BPHTB) merupakan salah satu sumber potensi pajak yang patut digali sesuai situasi dan kondisi perekonomian serta perkembangan pembangunan bangsa sekarang ini.(Pahala, 2003) Bea Perolehan Hak Atas Tanah dan Bangunan sebelum diberlakukannya (Undang-Undang Nomor 28 Tahun 2009 Tentang Pajak Daerah dan Retribusi Daerah, t.t.) merupakan pajak yang dipungut oleh pemerintah pusat. Dengan adanya era otonomi daerah dan sejak diundangkannya UndangUndang Nomor 28 Tahun 2009 tentang Pajak Daerah dan Retribusi Daerah maka telah terjadi pembaruan di bidang pajak daerah. BPHTB menjadi pajak daerah yang dipungut oleh pemerintah daerah kabupaten/kota.

Lahirnya (Undang-Undang Republik Indonesia Nomor 28 Tahun 2009 Tentang Pajak Daerah dan Retribusi Daerah, t.t.), merupakan implementasi atas lahirnya otonomi daerah yang diselenggarakan di Indonesia. Pajak daerah sebagai salah satu sumber Pendapatan Asli Daerah, merupakan sumber keuangan riil bagi pemerintah daerah. Suatu daerah mempunyai hak untuk mengatur, mendapatkan, dan memelihara aspek sumber Pendapatan Asli Daerahnya yang hasilnya 100\% (seratus persen) dikelola oleh pemerintah daerah itu sendiri. Penerapan Undang-Undang Republik Indonesia Nomor 28 Tahun 2009 Tentang Pajak Daerah dan Retribusi Daerah telah mengubah sistem pengelolaan Pajak Bumi dan Bangunan khususnya sektor Perdesaan dan Perkotaan. Pajak Bumi dan Bangunan Perdesaan dan Perkotaan (PBB P2) yang awalnya merupakan pajak pusat kini menjadi pajak 
daerah. Pengalihan pengelolaan Pajak Bumi dan Bangunan Perdesaan dan Perkotaan (PBBP2) dari Pemerintah Pusat kepada Pemerintah Daerah ini merupakan suatu bentuk tindak lanjut kebijakan otonomi daerah dan desentralisasi fiskal yang ada. Hasil dari pengelolaan pajak tersebut $100 \%$ (seratus persen) masuk ke kas daerah setempat, sehingga tidak akan ada lagi bagi hasil pajak kepada pemerintah pusat.

Menyikapi pelaksanaan (Undang-undang Nomor 28 Tahun 2009, Pemerintah Daerah Kabupaten Bogor telah mengeluarkan Peraturan Daerah Nomor 2 Tahun 2011 Tentang Bea Peralihan Hak atas Tanah dan Bangunan (BPHTB), t.t.). Dengan adanya pelimpahan wewenang tersebut Pemerintah Kabupaten Bogor berusaha membuat kebijakan-kebijakan untuk mencapai target yang telah ditetapkan. Kebijakan yang ditetapkan Pemerintah Kabupaten Bogor antara lain adalah menetapkan target-target yang harus dicapai oleh daerah dalam rangka pelaksanaan pemungutan Bea Perolehan Hak atas Tanah dan Bangunan. Dengan terbitnya Peraturan Daerah Kabupaten Bogor Nomor 2 Tahun 2014 tentang Perubahan Kedua Atas Peraturan Daerah Kota Bogor Nomor 4 Tahun 2011 tentang Pajak Daerah, maka fungsi pelaksanaan verifikasi dan pengesahan pembayaran BPHTB menjadi tugas Unit Pelayanan Pajak Daerah (UPPD), tepatnya Seksi Pendataan dan Pelayanan.

Verifikasi terhadap penerimaan BPHTB oleh DPKAD dilakukan setelah Wajib Pajak melakukan pembayaran di Kas Daerah atau tempat pembayaran lain yang ditunjuk. Verifikasi disini dimaksudkan untuk memonitor kebenaran Wajib Pajak dalam menghitung pajaknya.

Kegiatan peningkatan kualitas berupa membuat laporan dari hasil penelitian di lapangan tentang harga pasar, kondisi objek pajak seperti kualitas objek pajak, maupun fasilitas yang ada dari bangunan tersebut. Kegiatan ini sudah cukup baik apabila dilaksanakan dengan baik. Dengan melihat kondisi yang sesungguhnya, maka untuk menentukan besar BPHTB yang harus dibayarkan sesuai dengan teori pemungutan pajak.

Menurut Mardiasmo,(Mardiasmo, 2002) pemungutan pajak harus memenuhi persyaratan sebagai berikut :

1. Pemungutan pajak harus adil (syarat keadilan);

2. Pemungutan pajak harus berdasarkan undang-undang (syarat yuridis);

3. Tidak mengganggu perekonomian (syarat ekonomis);

4. Pemungutan pajak harus efesien (syarat finansial);

5. Sistem pemungutan pajak harus sederhana. 
Persyaratan-persyaratan dalam pemungutan pajak tersebut sudah selayaknya diperhatikan oleh pengambil kebijakan, agar dalam melaksanakan pemungutan pajak tidak membebani masyarakat. Kebijakan-kebijakan yang diambil oleh pemerintah daerah juga selayaknya memperhatikan keadilan dan kemanfaatan bagi warganya. Irfan Islamy (Irfan, 2000) mengatakan bahwa setiap kebijakan yang telah dibuat dan dilaksanakan akan membawa dampak tertentu terhadap kelompok sasaran, baik yang positif (intended) maupun yang negatif (unintended). Untuk itu tinjauan efektifitas kebijakan, selain pencapaian tujuan harus diupayakan pula untuk meminimalisir ketidakpuasan (dissatisfaction) dari seluruh stakeholder.

\section{Kendala Penentuan Harga Transaksi Peralihan Hak Dalam Verifikasi Bea Perolehan Hak} Atas Tanah dan Bangunan (BPHTB) Serta Solusi Penyelesaiannya

Dalam rangka pelaksanaan Peraturan Daerah Nomor 2 Tahun 2011 tentang Bea Perolehan Hak Atas Tanah dan Bangunan (BPHTB) dan peningkatan Pendapatan Asli Daerah (PAD), maka perlu adanya pengamanan penerimaan BPHTB mulai dari pendataan, verifikasi hingga pemberian surat tagihan kurang bayar BPHTB.

Dinas Pengelolaan Keuangan dan Aset Daerah Kabupaten Bogor setelah melakukan verifikasi terhadap kelengkapan dokumen dan kebenaran data terkait objek pajak yang tercantum dalam SSPD BPHTB kemudian menetapkan Surat Tagihan Pajak Daerah BPHTB untuk BPHTB yang menurut DPKAD tidak/kurang dibayar, salah tulis, salah hitung dan kena bunga atau denda.

Sehubungan dengan hal tersebut maka Badan Pertanahan Nasional menerbitkan Surat Edaran Kepala Badan Pertanahan Nasional Republik Indonesia Nomor. 5/SE/IV/2013 tentang Pendaftaran Hak Atas Tanah Atau Peralihan Hak Atas Tanah Terkait Dengan Pelaksanaan Undang-undang Nomor 28 Tahun 2009 tentang Pajak Daerah dan Retribusi Daerah, dengan tidak mempersyaratkannya proses validasi atau pengecekan tanda bukti setoran BPHTB di DPKAD sehingga surat edaran ini dikeluarkan untuk percepatan dalam hal validasi.

Berdasarkan penelitian, ada beberapa hal yang menjadi kendala dalam realisasi pemungutan atau penerimaan Pajak BPHTB dalam pelaksanaan perolehan hak atas tanah dan bangunan lebih dari satu kali dalam tahun yang sama sehingga mempengaruhi kelancaran pelayanan kepada masyarakat. Kendala-kendala tersebut antara lain :

a. Pajak Bea Perolehan Hak atas Tanah dan Bangunan (BPHTB) berbeda dengan jenis Pajak Daerah yang lain. Pajak Daerah selain BPHTB dapat diperhitungkan jumlah potensinya secara terus menerus dan berkesinambungan, sedangkan pajak BPHTB sangat bergantung dari transaksi yang terjadi. Apabila tidak terjadi peralihan tanah dan bangunan maka tidak akan ada pemungutan pajak BPHTB. 
b. Ditiadakannya validasi BPHTB dalam setiap transaksi jual beli mempengaruhi jumlah pajak yang harus dibayarkan oleh Wajib Pajak. Faktor kejujuran dari wajib pajak sangat diperlukan dalam membayar BPHTB sesuai harga transaksi agar realisasi pendapatan daerah dari BPHTB dapat memenuhi target yang telah ditetapkan.

c. Kurangnya jumlah personil yang ahli di DPKAD. Jumlah personil yang kurang mengakibatkan terbatasnya sosialisasi yang dilakukan dan mengakibatkan dalam pelaksanaan tugas sehari- hari tidak bisa fokus dan maksimal.

d. Transaksi yang dilaporkan pada saat pengisian SSPD BPHTB tidak sesuai harga transaksi yang riil tetapi sesuai dengan Nilai Jual Objek Pajak yang tertera pada SPPT PBB, padahal Nilai Jual Objek Pajak yang tertera pada SPPT PBB biasanya lebih kecil dari nilai transaksi yang riil.

Berdasarkan data yang diperoleh dari responden, kendala-kendala yang mempengaruhi kelancaran pelayanan kepada masyarakat, antara lain :

a. Minimnya sosialisasi pembayaran BPHTB oleh instansi terkait, sehingga mengakibatkan masyarakat mempercayakan kepada Notaris/PPAT dalam pembayaran BPHTB.

b. Tarif Bea Perolehan Hak atas Tanah dan Bangunan (BPHTB) sebesar 5\% (lima persen) dari harga transaksi dirasa terlalu tinggi bagi masyarakat.

c. Adanya pungutan yang tinggi dari pihak kelurahan apabila dimintai surat kelengkapan bukti fisik dalam hal tanahnya belum bersertipikat.

Pada praktiknya, sistem Self Assessment ini masih terbentur dengan beberapa kendala, diantaranya sebagai berikut :

1. Kepercayaan yang diberikan oleh pemerintah kepada masyarakat untuk menghitung/memperhitungkan, membayar dan melaporkan pajaknya sendiri masih diragukan kebenarannya, oleh karena itu dapat menimbulkan terjadinya penyeludupan pajak karena yang mengetahui kebenaran SPT yang dilaporkan Wajib Pajak hanya Wajib Pajak itu sendiri.

2. Masih banyaknya Wajib Pajak yang kesulitan untuk menghitung/memperhitungkan pajak yang terutang, karena di dalam undang-undang tidak dijelaskan secara terinci bagaimana menghitung pajak terutang untuk berbagai jenis usaha, sehingga banyak perusahaan yang akhirnya melakukan kesalahan dalam menghitung pajak terutangnya. Lain halnya ketika Wajib Pajak harus melakukan rekonsiliasi laporan keuangan komersial sesuai dengan ketentuan peraturan perundang-undangan perpajakan menjadi laporan keuangan fiskal. Seperti yang dilakukan di Belanda, dimana laporan keuangan fiskal merupakan by product dari akuntansi komersial. 
3. Kendala juga tidak terjadi di pihak Wajib Pajak, di pihak fiskus juga terjadi masalah yaitu terbatasnya akses data Wajib Pajak yang dimiliki oleh pihak ketiga sehingga mempersulit Dirjen Pajak untuk mendeteksi kebenaran isi SPT yang dilaporkan Wajib Pajak, sehingga pengawasan belum dapat dilakukan secara optimal.

Selama ini pengukuran keberhasilan maupun kegagalan dari instansi pemerintah dalam menjalankan tugas pokok dan fungsinya sulit untuk dilakukan secara objektif. Pengukuran kinerja suatu instansi hanya lebih ditekankan kepada kemampuan instansi tersebut dalam menyerap anggaran atau mengerjakan tugas-tugas pokok yang telah digariskan. Untuk dapat mengetahui tingkat keberhasilan suatu instansi pemerintah, maka seluruh aktivitas instansi tersebut harus dapat diukur yang meliputi input (masukan), output (keluaran), outcomes (hasil), benefits (manfaat) dan impact. (Mahsun, 2006)

Implementasi kebijakan akan berhasil jika ada dukungan dari masyarakat langsung dalam hal ini Wajib Pajak BPHTB. Dukungan publik adalah kemampuan masyarakat untuk mendukung atau tidak mendukung terhadap adanya kegiatan yang diselenggarakan oleh Dinas Pengelolaan Keuangan dan Aset Daerah. Dukungan publik dapat diartikan sebagai partisipasi masyarakat atau wajib pajak dalam implementasi kebijakan Bea Perolehan Hak atas Tanah dan Bangunan.

\section{Simpulan}

Pelaksanaan Penentuan Harga Transaksi Peralihan Hak Dalam Verifikasi Bea Perolehan Hak Atas Tanah Dan Bangunan (BPHTB) di Kabupaten Bogor adalah berdasarkan nilai transaksi yang terjadi atas jual beli sesuai dengan kwitansi atau sebagaimana tercantum dalam Akta Jual Beli atau sesuai bukti otentik lainnya yang dapat dipertanggungjawabkan oleh Wajib Pajak. Pada prakteknya apabila nilai transaksi lebih rendah dari NJOP maka nilai NJOP tersebut yang digunakan sebagai dasar penetapan pajak. Sebaliknya apabila nilai transaksi lebih tinggi dari NJOP maka harga transaksi tersebut lah yang digunakan sebagai dasar penetapan pajak. Berkaitan dengan verifikasi terhadap penerimaan BPHTB oleh DPKAD dilakukan setelah Wajib Pajak melakukan pembayaran di Kas Daerah atau tempat pembayaran lain yang ditunjuk. Verifikasi disini dimaksudkan untuk memonitor kebenaran Wajib Pajak dalam menghitung pajaknya. Proses verifikasi terhadap penerimaan BPHTB dan penerbitan Surat Keputusan Pajak Daerah (SKPD) kurang bayar BPHTB/kurang bayar tambahan BPHTB oleh DPKAD ini seringkali menimbulkan masalah bagi pelaksanaan pendaftaran peralihan hak karena jual beli, karena dengan adanya penentuan besaran BPHTB yang harus dibayarkan ini DPKAD dianggap menghambat proses transaksi jual beli dan pendaftaran peralihan hak atas tanah. Jual beli pada dasarnya adalah kesepakatan para pihak, sedang dengan adanya verifikasi mengenai NJOP-BPHTB akan membuat 
perjanjian jual beli tersebut dibuat bukan karena adanya kesepakatan para pihak akan tetapi paksaan dari instansi pemerintah.

Kendala Penentuan Harga Transaksi Peralihan Hak Dalam Verifikasi Bea Perolehan Hak Atas Tanah dan Bangunan (BPHTB) Serta Solusi Penyelesaiannya yaitu: ditiadakannya validasi BPHTB dalam setiap transaksi jual beli mempengaruhi jumlah pajak yang harus dibayarkan oleh Wajib Pajak, faktor kejujuran dari wajib pajak sangat diperlukan dalam membayar BPHTB sesuai harga transaksi agar realisasi pendapatan daerah dari BPHTB dapat memenuhi target yang telah ditetapkan, kurangnya jumlah personil yang ahli di DPKAD. Jumlah personil yang kurang mengakibatkan terbatasnya sosialisasi yang dilakukan dan mengakibatkan dalam pelaksanaan tugas sehari- hari tidak bisa fokus dan maksimal, transaksi yang dilaporkan pada saat pengisian SSPD BPHTB tidak sesuai harga transaksi yang riil tetapi sesuai dengan Nilai Jual Objek Pajak yang tertera pada SPPT PBB, padahal Nilai Jual Objek Pajak yang tertera pada SPPT PBB biasanya lebih kecil dari nilai transaksi yang riil. Pemerintah Kabupaten Bogor jika ditinjau dari segi pelayanan, maka sebagai instansi yang memberikan pelayanan dalam hal pembayaran pajak Bea Perolehan Hak atas Tanah dan Bangunan, maka diukur dari segi pelayanan yang dihasilkan. Pengukuran keberhasilan pelayanan dapat dilakukan dengan berbagai macam parameter. Implementasi kebijakan akan berhasil jika ada dukungan dari masyarakat langsung dalam hal ini Wajib Pajak BPHTB. Dukungan publik adalah kemampuan masyarakat untuk mendukung atau tidak mendukung terhadap adanya kegiatan yang diselenggarakan oleh Dinas Pengelolaan Keuangan dan Aset Daerah. Dukungan publik dapat diartikan sebagai partisipasi masyarakat atau wajib pajak dalam kebijakan Bea Perolehan Hak atas Tanah dan Bangunan.

\section{DAFTAR PUSTAKA}

\section{Buku}

Amiruddin, dan Zainal Asikin,. 2004. Pengantar Metode Penelitian Hukum. Jakarta: Raja Grafindo Persada.

Bohari, H. 2008. Pengantar Hukum Pajak, ed. revisi. Jakarta: PT Raja Grafindo Persada.

Budi, Winarno. 2007. Kebijakan Publik Teori dan Proses. Yogyakarta: Media Pressindo.

Damayanti, Supramono dan Theresia Woro. 2005. Perpajakan Indonesia - Mekanisme dan Penghitungan, Ed. 1,. Yogyakarta: Andi.

Harsono, Budi. 2007. Hukum Agraria Indonesia. Jakarta: Djambatan.

Irfan, Islamy, M. 2000. Prinsip-Prinsip Perumusan Kebijaksanaan Negara. Jakarta: Bumi Aksara. 
Kementerian Keuangan Republik Indonesia, Direktorat Jenderal Perimbangan Keuangan,. 2011. Tinjauan Pelaksanaan Pengalihan Bea Perolehan Hak atas Tanah dan Bangunan (BPHTB) Menjadi Pajak Daerah. Jakarta.

Mahsun, Mohammad. 2006. Pengukuran Kinerja Sektor Publik. Yogyakarta: BPFF.

Mardiasmo,. 2002. Perpajakan. Yogyakarta: Andi.

Marzuki, Peter Mahmud. 2008. Pengantar Ilmu Hukum. Jakarta: Kencana.

Munawir,. 1992. S. Perpajakan. Ed. 4. Cet. 1. Yogyakarta: Liberty.

Nurmana, Safri. 2003. Pengantar Perpajakan. Jakarta: Obor Indonesia.

Pahala, Siahaan, Marihot. 2003. Bea Perolehan Hak atas Tanah dan Bangunan, Teori dan Praktik, Edisi Revisi. Jakarta: Rajawali Pers.

Rahardjo, Satjipto. 2009. Sisi-Sisi Lain dari Hukum di Indonesia,. Jakarta: Kompas Media Nusantara.

Rashid, Harun Al. 1987. Sekilas tentang Jual Beli Tanah (Berikut Peraturan-peraturannya). Jakarta: Ghalia Indonesia.

Rusjdi, Muhammad. 2005. PBB, BPHTB, \& Bea Materai. Jakarta: PT Indeks.

Siahaan, Marihot Pahala. 2004. Utang Pajak, Pemenuhan Kewajiban dan Penagihan Pajak dengan Surat Paksa, cet. 1. Jakarta: Raja Grafindo Persada.

Soekamto, Soerjono. 2001. Sosiologi Suatu Pengantar. Jakarta: Raja Gravindo Persada.

Soekanto, Soerjono, dan Sri Mamudji,. 2003. Penelitian Hukum Normatif Suatu Tinjauan Singkat. Jakarta: Raja Grafindo Persada.

Solly, Lubis. 2014. Politik Hukum dan Kebijakan Publik. Bandung: Mandar Maju.

Sudirman,. 2007. Hati nurani hakim dan putusannya, suatu pendekatan dari perspektif ilmu hukum perilaku (behavioral jurisprudence): Kasus hakim Bismar Siregar. Bandung: Citra Aditya Bakti

\section{Artikel Jurnal}

Alwi, Eka Yulianti, dan Yuslim,. 2018. "Penentuan Harga Jual Beli Tanah Dalam Pemungutan Bea Perolehan Hak Atas Tanah Dan Bangunan Di Kota Pekanbaru.” Fakultas Hukum, Universitas Andalas.

Maulidah, Zahrotul. 2015. "Mekanisme Dalam Menentukan Nilai Pasar Pada Pemungutan Bphtb Atas Waris Di Kota Surabaya Oleh Dinas Pendapatan Dan Pengelolaan Keuangan Kota Surabaya.” FAKULTAS HUKUM UNIVERSITAS BRAWIJAYA MALANG. 
Murjiyanto, R., dan Samun Ismaya,. 2015. "Kepastian Nilai Dasar Penghitungan Bea Perolehan Hak Atas Tanah dan Bangunan (BPHTB)." Fakultas Hukum Universitas Janabadra.

\section{Undang-undang}

Undang-undang Nomor 28 Tahun 2009, Pemerintah Daerah Kabupaten Bogor telah mengeluarkan Peraturan Daerah Nomor 2 Tahun 2011 Tentang Bea Peralihan Hak atas Tanah dan Bangunan (BPHTB). t.t.

Undang-Undang Nomor 28 Tahun 2009 Tentang Pajak Daerah dan Retribusi Daerah. t.t.

Undang-Undang Republik Indonesia Nomor 28 Tahun 2009 Tentang Pajak Daerah dan Retribusi Daerah. t.t. 